ELEOS: Jurnal Teologi dan Pendidikan Agama Kristen

Sekolah Tinggi Teologi Kalvari Manado

ISSN 2798-9771 (Online), 2798-9860 (Print)

Volume. 1, Nomor. 2, Edisi Januari 2022 (Hal. 111-125)

DOI: $10.53814 /$ eleos.v1i2.9

https://sttkalvari.ac.id/ojs/index.php/eleos/index

\title{
Konsep Pisah Ranjang dalam Sifat tak-terputuskan Perkawinan Katolik: Analisis Kanon 1151-1155
}

\author{
${ }^{1}$ Mathias Jebaru Adon, ${ }^{2}$ Hyronimus Ario Dominggus \\ ${ }^{1,2}$ Sekolah Tinggi Filsafat Widya Sasana Malang \\ ${ }^{1}$ mathiasjebaruadon@gmail.com, ${ }^{2}$ ariomontfortan@gmail.com
}

\begin{abstract}
The purpose of this study is to examine the meaning of "separate bed" in the concept of the unbreakable nature of a Catholic marriage. The Catholic Church in essence highly values the essential nature of marriage, which is one and indivisible. This also emphasizes that the Catholic Church does not want a divorce. The church only recognizes "bed separation" in the context of husband and wife who want to separate. The Code of Canon Law (Can. 1151-1155) is very clear and detailed what this "bed separation" means. In addition, "separate bed" is an opportunity for husband and wife who are separated to introspect each other. This research was conducted using a library research method which is descriptive in a Catholic Church Law perspective. From this research, We found the basic point of what the meaning of "separation of bed" in the Catholic Church is that distinguishes it from the road to divorce. In other words, separation in the Catholic Church will not eliminate the unbreakable nature of marriage, unless death separates it.
\end{abstract}

Keywords: Marriage, Separate Bed, Marriae Law of Catholic Church, Indivisible Nature of Marriage

Abstrak: Penelitian studi ini memiliki tujuan menelaah makna "pisah ranjang" dalam konsep sifat tak-terputuskannya Perkawinan Katolik. Gereja Katolik pada intinya sangat menghargai sifat hakiki dalam perkawinan yakni satu dan tak-terputuskan. Hal ini pun mau menegaskan bahwa Gereja Katolik tidak menginginkan adanya perceraian. Gereja hanya mengenal "pisah ranjang" untuk konteks suami-istri yang memang ingin berpisah. Kitab Hukum Kanonik (Kan. 1151-1155) dengan sangat jelas dan terperinci bagaimana arti dari "pisah ranjang” ini. Selain itu, "pisah ranjang" sejatinya menjadi kesempatan untuk suami-istri yang berpisah untuk saling menginstropeksi diri. Penelitian ini dilakukan dengan menggunakan metode penelitian studi pustaka yang bersifat deskriptif dalam perspektif Hukum Gereja Katolik. Dari penelitian ini, kami menemukan titik dasar apa makna "pisah ranjang" dalam Gereja Katolik yang membedakannya dengan jalan menuju perceraian. Dengan kata lain, berpisah dalam Gereja 
Jefrie Walean: Polemik Memakan Darah: Studi Kasus dalam Sidang di Yerusalem

Katolik tidak akan menghilangkan sifat tak-terputuskan Perkawinan, kecuali maut memisahkannya.

Kata Kunci: Perkawinan, Pisah Ranjang, Hukum Perkawinan Gereja Katolik, Sifat Perkawinan tak terceraikan.

\section{Pendahuluan}

Perkawinan dalam tatanan hidup bersama masih menjadi sistem sosial yang cukup berpengaruh. Hal yang perlu dicatat bahwa hampir pasti dalam semua kebudayaan perkara perkawinan juga menjadi bagian vital kehidupan. Perkawinan menjadi bagian atau tahap dalam proses kehidupan. Oleh karena itu perkawinan selalu bersentuhan dengan budaya bahkan menjadi salah satu unsur kebudayaan manusia. Itulah sebabnya perkawinan dipahami sebagai suatu institusi sosial yang selali diatur secara baik dalam menunjang keteraturan tatanan hidup sebuah bermasyarakat. ${ }^{1}$

Selain ranah budaya, dalam konteks agama, perkawinan juga mendapat ruang dan tempat yang istimewa. Dalam arti ini agama menjadi sistem sosial yang memperkuat legitimasi sebuah perkawinan. Asumsi dasar tersebut mengindikasikan betapa pentingnya sebuah perkawinan sebagai sebuah tahap baru dalam kehidupan manusia. Dengan perkawinan memaksudkan tahap kehidupan baru sebagai sebuah keluarga. Setiap agama tentu saja memiliki paham dan sistem perkawinan yang berbeda satu sama lain. Walaupun berbeda, tetapi dalam arti tentu setiap agama berusaha menjadikan perkawinan sebagai sarana dan sistem yang bertujuan menyatukan pasangan suami isteri dalam tahap kehidupan baru.

Perkawinan sebagai sistem sosial bukan berarti tanpa tantangan. Fenomena keretakan rumah tangga yang berujung pada perceraian semakin marak terjadi saat ini. Perkawinan yang dinilai sebagai sebuah tahap yang "sakral" terutama dalam pandangan agama maupun budaya berada pada titik pudar yang ekstrim. Perceraian adalah salah satu penyebab runtuhnya kesakralan perkawinan ini. Dapat dikatakan perceraian menjadi sebuah mimpi buruk yang menggerogoti impian keluarga-keluarga yang selalu mengarahkan kehidupan keluargannya pada suasana bahagia dan sejahtera satu untuk selamanya. ${ }^{2}$

Di Indonesia, fenomena perceraian bukanlah perkara baru dan bahkan mengalami peningkatan dari tahun ke tahun. Dari data Badan Pusat Statistik Nasional Indonesia, talak dan perceraian pada tahun 2016 berjumlah 365.633 kasus. $^{3}$ Selain itu, data dari Dirjen Bina Masyarakat Islam, Kementerian Agama mencatat rata-rata 300 ribu angka perceraian di

${ }^{1}$ Sujarwa, Ilmu Sosial Dan Budaya Dasar, Manusia Dan Fenomena Sosial Budaya (Yogyakarta: Pustaka Pelajar, 2010): 27-28.

${ }^{2}$ Yohanes Servatius Lon, Hukum Perkawinan Sakramental Dalam Gereja Katolik (Yogyakarta: Kanisius, 2019): 42.

3 Badan Pusat Statistik, "Jumlah Nikah, Talak Dan Cerai, Serta Rujuk (Pasangan Nikah), 2014-2016,", https://www.bps.go.id/indicator/27/176/1/jumlah-nikah-talak-dan-cerai-serta-rujuk.html, diakses pada 21 September 2021. 
Indonesia setiap tahun. ${ }^{4}$ Data-data menunjukkan secara jelas fakta marak terjadinya perceraian dalam kehidupan masyarakat Indonesia saat ini baik yang sedang diproses maupun yang sudah diputuskan dalam pengadilan. Meski harus diakui bahwa keputusan untuk berpisah atau bercerai tentu selalu dilandasi oleh alasan yang jelas dan dilandasi atas dasar pertimbangan yang matang.

Berhadapan dengan fenomena perceraian ini, setiap kebudayaan dan juga agama memiliki pandangan tersendiri. Menarik bahwa dalam tradisi Gereja Katolik, tidak dikenal istilah perceraian. Hal ini terjadi karena Gereja senantiasa menjaga kesakralan atau kesucian perkawinan yang satu tak terputuskan kecuali maut yang memisahkan. Atas dasar itu, Gereja Katolik menempatkan perkawinan sebagai sebuah sakramen. Konsili Vatikan II menegaskan bahwa di dalam ikatan perkawinan suci tersebut, suami dan istri menandakan dan menghadirkan misteri kesatuan dan cinta kasih yang subur antara Kristus dan Gereja, dan ikut serta menghayati misteri itu (lih. Ef. 5:32). ${ }^{5}$ Hal ini tentu saja tidak terlepas dari keyakinan bahwa sifat perkawinan adalah monogami dan tak-terputuskan. Dengan komitmen ini, Gereja sangat menghormati dan menjunjung tinggi perkawinan. Terkait hal ini Kitab Hukum Kanonik Gereja Katolik Kan. 1141 menegaskan bahwa perkawinan dalam Gereja Katolik sifatnya ratum dan consummatum. Artinya, perkawinan itu tidak dapat diputus oleh kuasa manusiawi manapun dan atas alasan apapun, selain oleh kematian. ${ }^{6}$

Meski hukum Gereja Katolik berlaku demikian namun harus diakui fakta kasus perceraian tetap melanda keluarga-keluarga Katolik. Entah itu dilakukan oleh pasangan yang sudah mengenal dengan baik sifat dan hakikat perkawinan Katolik yang satu dan tak tercerikan maupun pasangan yang belum mengerti hakikat dan sifat perkawinan Katolik. Berdasarkan sifat perkawinan Gereja katolik yang satu tak terceraikan tersebut, Gereja Katolik pada hakikatnya tidak menerima perceraian atas dasar alasan apapun kecuali maut memisahkan. Hal ini berarti dalam Gereja Katolik tidak dikenal perceraian.

Hal ini dijamin dan dilindungi oleh Kitab Hukum Kanonik Gereja Katolik kanon 1056 yang menyatakan ialah unitas (kesatuan) dan indissolubilitas (sifat tak-dapat-diputuskan) dan hal ditegaskan kembali dalam kanon 1057 bahwa perkawinan pada hakikatnya adalah tindakan kehendak dengannya seorang laki-laki dan seorang wanita saling menyerahkan diri dan saling menerima untuk membentuk perkawinan dengan perjanjian yang tak dapat ditarik kembali. Hal ini berarti pristiwa perkawinan lahir dari kehendak bebas dan dilandasi alasan yang cukup sehingga seorang pria dan wanita mengambil keputusan untuk menyerahkan hidup bagi pasangannya guna membangun sebuah keluarga.

4 CNN Indonesia Tim, "Catatan Kemenag: Rata-Rata 300 Ribu Perceraian Tiap Tahun," (2021), https://www.cnnindonesia.com/nasional/20201218113251-20-583771/catatan-kemenag-rata-rata-300-ribuperceraian-tiap-tahun, diakses pada 21 September 2021.

5 Konsili Vatikan II, Lumen Gentium (Terang Bangsa-Bangsa) (Jakarta: Dokumentasi dan Penerangan KWI, 1990): 25.

${ }^{6}$ Yohanes Paulus II, Kitab Hukum Kanonik (Codex Iuris Canonici) (Jakarta: Konferensi Wali Gereja Indonesia, 1983). 
Atas dasar ini Gereja Katolik hanya mengenal istilah pemutusan atau pembatalan ikatan nikah. Berkaitan dengan itu, perlu dilihat juga bahwa dari sejarah yurisprudensi kanonik, kelihatan bahwa dalam situasi tertentu dan dengan syarat-syarat tertentu pula Gereja mengizinkan pemutusan beberapa ikatan nikah yang tidak sekaligus ratum dan consumatum. ${ }^{7}$ Sebab Gereja Katolik dalam hal ini sangat tegas pada komitmen untuk mempertahankan keutuhan perkawinan dan rumah tangga pasangan suami-isteri. Namun demikian, sebagaimana yang telah disebutkan di atas, ada kasus khusus di mana kuasa tertinggi Gereja Katolik dapat memberikan pengecualian dengan membatalkan (anulasi) perkawinan. Anulasi dimengerti sebagai proses yuridis Gereja, yang menegaskan bahwa perkawinan tersebut sedari awal tidak sah karena ada syarat-syarat demi keabsahannya yang tidak terpenuhi. ${ }^{8}$ Dengan kata lain, pemutusan hubungan perkawinan diambil karena sedari awal perkawinan itu tidak sah dan tidak memenuhi tuntutan dan syarat perkawinan Katolik yang satu tak terceraikan.

Dalam menangani perkara perkawinan tersebut, Gereja Katolik sendiri memiliki pengadilan khusus yang diurus oleh Vikaris Yudensial. Perkara perkawinan dalam Gereja Katolik juga mengurus perpisahan yang sifatnya sempurna (divirtio) dan juga yang sementara. Yang bersifat sempurna ini lebih terarah pada pemutusan ikatan perkawinan sehingga kedua pasangan dapat dengan bebas untuk menikah. Lalu bagaimana dengan konteks perpisahan yang tetap memiliki ikatan perkawinan Gereja Katolik yang satu tak terpisahkan. Hal menarik untuk didalami karena Gereja Katolik juga memberikan penekankan pada perkara perpisahan perkawinan secara tidak sempurna. Istilah ini berkaitan dengan konsep "pisah ranjang” dalam sistem perkawinan Gereja Katolik.

Hal ini didasarkan karena tidak jarang dalam keluarga-keluarga Katolik terdapat kasus dimana pasangan memilih berpisah dengan berbagai alasan walaupun belum mengajukan permohonan pemutusan ikatan perkawinan kepada Vikaris Yudensial. Berkaitan dengan kasus semacam ini Gereja Katolik memberikan kesempatan "pisah ranjang” bagi pasangan yang memang tidak bisa dipertahankan. Kesempatan diberikan kepada pasangan yang sejak awal telah memenuhi tuntutan dan syarat-syarat perkawinan Katolik yang satu tak terceraikan dan sarana ini diberikan atau dianjurkan Gereja karena sifat dasar perkawinan yang satu tak terceraikan tersebut.

Berkaitan konsep "pisah ranjang” tersebut dalam Gereja Katolik sudah diatur dalam Kitab Hukum Kanonik artikel 2 (Kanon 1151-1155) dari Bab XI yang diberi judul berpisah dengan tetap adanya ikatan perkawinan. Perlu dipahami di sini bahwa Kanon 1151-1155 membahas secara khusus perpisahan perkawinan secara tidak sempurna dalam arti ikatan perkawinan sendiri masih tetap ada karena yang dipisahkan hanyalah kebersamaan pasangan menyangkut

${ }^{7}$ Robertus Rubiyatmoko, Perkawinan Katolik Menurut Kitab Hukum Kanonik (Yogyakarta: Kanisius, 2011): 153 .

${ }^{8}$ Daniel Ortega Galed and Latar Belakang, "Perkawinan In Fieri Dan Perkawinan In Facto Esse Dalam Pemahaman Yuridis Gereja Katolik,” Hukum Magnus Opus 3, no. 1 (2020): 57-68. 
soal ranjang, meja, dan tempat tinggal (separatio tori, separatio mensare, dan separatio domus). ${ }^{9}$

Berdasarkan hal tersebut, penelitian ini bertujuan menggali secara lebih dalam sikap Gereja Katolik menangani persoalan “perpisahan” dalam perkawinan. Oleh karena itu, penelitian ini menggunakan Kanon 1151-1155 sebagai dasar rujukan penulis dalam memahami menangani persoalan perkawinan dalam Gereja Katolik. Selain itu, penelitian ini dilatarbelkangi keperihatin penulis karena masih begitu banyak umat Katolik yang belum memahami dengan baik persoalan pisah ranjang dalam konsep perkawinan Gereja Katolik yang satu tak terceraikan. Di samping itu, kerapkali umat Katolik melihat Pengadilan Gereja Katolik semacam "lembaga" yang dapat memutuskan perceraian atau menyetujui perceraian, padahal pandangan tersebut jelas bertentangan dengan sifat dasar perkawinan Gereja Katolik. Selain itu dalam pandangan Gereja Katolik "pisah ranjang" bukanlah sarana atau jalan untuk memutuskan ikatan perkawinan, tetapi suatu sarana yang digunakan oleh Gereja agar pasangan dapat menginstropeksi dan mengevaluasi perjalanan perkawinan tersebut. Oleh karena itu penelitian ini memberi pencerahan kepada umat Katolik akan hakikat dan sifat perkawinan Gereja Katolik yang satu tak terceraikan. Dengan kata lain, penelitian dapat menjadi katekese yang komprehensif berkaitan dengan persoalan perkawinan dalam Gereja Katolik.

\section{Metode Penelitian}

Penelitian ini dilakukan dengan menggunakan metode studi pustaka yang bersifat deskriptif dalam perspektif Hukum Perkawinan Gereja Katolik. Sumber data penelitian dibagi menjadi dua bagian yakni sumber data primer dan sumber data sekunder. Sumber data primer berasal dari Kitab Hukum Kanonik Gereja Katolik secara khusus yang berbicara tentang pisah ranjang yakni Kanon 1151-1155. Sedangkan sumber data sekunder berasal dari jurnal-jurnal yang berbicara secara khusus persolan perkawinan dalam Gereja Katolik mengenai pisah ranjang. Untuk mendukung data penelitian ini, penulis juga menggunakan sumber-sumber yang berasal dari buku-buku dan sumber pemberitaan online yang relevan dengan tesis penelitian. Penelitian ini menemukan bahwa pisah ranjang dalam konteks Gereja Katolik menjadi tidak terpisahkan dari sifat perkawinan katolik yang tidak terceraikan. Oleh karena itu, hasil penelitian ini memberikan pengetahuan berkaitan dengan pandangan Gereja Katolik tentang pisah ranjang dalam hubungannya dengan sifat perkawinan katolik yang tidak terceraikan.

\section{Hasil dan Pembahasan}

\section{Sifat Perkawinan Gereja Katolik}

Konsep "pisah ranjang" dalam konteks perkawinan katolik tidak pernah terlepas dari pemahaman tentang sifat perkawinan itu sendiri. Karena saling berkaitan satu sama lain, maka dalam uraian ini, pertama-tama penulis menjabarkan secara singkat mengenai sifat perkawinan dalam Gereja Katolik. Hal ini sangat penting dan mendasar untuk memahami mengapa Gereja

\footnotetext{
${ }^{9}$ Rubiyatmoko, Perkawinan Katolik Menurut Kitab Hukum Kanonik.,176.
} 
Katolik sangat menghargai dan menghormati perkawinan sehingga tidak menginginkan adanya perpisahan. Apa dan bagaimana sifat perkawinan tersebut akan diuraikan sebagai berikut.

\section{Kesatuan (unity) atau monogami}

Gereja Katolik menegaskan bahwa perkawinan adalah suatu persekutuan seorang pria dan seorang wanita dalam kesadaran penuh serta dengan penuh kebebasan mempersembahkan seluruh diri serta segala kemampuan satu sama lain untuk selama-lamanya. ${ }^{10}$ Kesatuan dalam hal ini menjadi inti yang memungkinkan sebuah perkawinan Katolik utuh selamanya. Tentu saja kesatuan tersebut selalu mengandaikan kebebasan penuh dari seorang pria dan seorang wanita. Keduanya bersatu untuk mempersembahkan diri satu sama lain tanpa saling menduakan. Artinya jika seorang pria sudah memilih untuk menikah dengan seorang wanita begitu sebaliknya berarti tidak boleh lagi memilih pasangan lain kecuali maut yang memisahkan.

Kesatuan (monogami) dalam hal ini juga merujuk pada ke-satu-an (unitas, unity) yakni relasi antara seorang pria dan seseorang wanita untuk hidup sebagai suami-istri selamanya melalui perjanjian yang bersifat ekslusif. ${ }^{11}$ Eksklusivitas dalam hal ini menggambarkan betapa sebuah perkawinan itu suci dan sangat dihormati. Jadi sangat jelas bahwa hanya seorang pria dan seorang wanita sajalah yang menjadi pasangan suami-isteri dan bersifat kekal sampai maut memisahkan. Gereja menekankan hal ini bukan tanpa alasan. Kitab Suci sendiri telah menunjukkan betapa perkawinan bersifat monogami itu sangat penting. Dalam hal ini Kitab Kejadian bagaimana kesatuan itu digambarkan dengan sangat mendalam yakni dengan frasa "Keduanya menjadi satu daging". Artinya jika seseorang mau memberikan seluruh dirinya kepada orang yang dicintainya, dan sekaligus menerimanya secara sama dalam perkawinan, maka kesepakatan timbal-balik itu tidak bisa diberikan lagi kepada orang ketiga atau keempat, dan seterusnya (bdk. Kan. 1135).

Konsekuensi logis dari gagasan kesatuan perkawinan ini ialah bahwa orang yang sudah terikat oleh perkawinan sah dengan sendirinya tidak bisa menikah lagi secara sah dengan orang lain. Dengan kata lain hanya mautlah yang memisahkan keduanya. Maka konsekuensi lebih lanjutnya ialah ikatan nikah yang pertama menjadi halangan yang sifatnya menggagalkan bagi pernikahan yang kedua (bdk. Kan. 1085). Oleh karena itu, Gereja Katolik menekankan bahwa ketika pasangan pria dan wanita memilih untuk menikah secara Katolik berarti diandaikan bahwa pasangan tersebut mengerti konsekuensinya yakni bahwa mereka hanya bisa menikah sekali untuk selamnya sampai maut memisahkan keduanya.

\section{Tak-terputuskan (indissolubility)}

Selain sifatnya monogami, perkawinan katolik juga memiliki Sifat yang tidak kalah penting yakni tak-terputuskan atau tak terceraikan (indissolubilitas, indissolubility). Terkait

${ }^{10}$ Alfian Hadyanto Purnadi, "Perpisahan Hidup Perkawinan Menurut Kitab Hukum Kanonik (KHK) Kanon 1151-1155 Dalam Hubungannya Dengan Sistem Perundangan Indonesia,” Lex et Societatis II, no. 3 (2014).

${ }^{11}$ A. Tjatur Raharso, Paham Perkawinan Gereja Katolik (Malang: Dioma, 2014): 95. 
sifat tak-terceraikan ini, St. Agustinus menyebutnya sebagai bonum sacramenti. Sifat ini menegaskan bahwa ikatan nikah bersifat absolut, eksklusif, dan berlangsung seumur hidup, serta tidak bisa diputus selain oleh kematian. Bertolak dari asumsi dasar tersebut, Gereja Katolik sangat "radikal" dalam mengakui dan mempertahankan keutuhan perkawinan sehingga tidak boleh diceraikan oleh manusia. Hal ini mengindikasikan bahwa perkawinan yang telah diselenggarakan secara sah menurut tuntutan hukum, memiliki efek atau akibat tetap dan tidak dapat diceraikan oleh kuasa mana pun kecuali kematian. ${ }^{12}$

Lebih jauh ditekankan bahwa sifat tak terceraikan ini menjadikan perkawinan katolik itu sendiri bersifat abadi atau kekal. ${ }^{13}$ Tentu saja yang hendak dikatakan adalah kesakralan atau kesucian sebuah perkawinan tidak hanya urusan manusia tetapi juga keterlibatan Allah. Karena ada campur tangan Allah, maka manusia tidak punya hak untuk "menghancurkan" perkawinan tersebut. Asumsi dasar ini dipertegas dengan keyakinan bahwa tak terputuskan atau tak terceraikannya perkawinan adalah kehendak dan rencana Allah sedari awal penciptaan, ketika Ia mempersatukan mereka (pria dan wanita) dalam perkawinan. ${ }^{14}$ Selain itu, Kristus sendiri telah mengatakan bahwa "apa yang telah dipersatukan oleh Allah, janganlah diceraikan oleh manusia" (Mat 19: 8).

Maka Gereja mengikuti dan melanjutkan pola yang ditunjukkan Kristus dengan terus menerus membela keutuhan perkawinan dengan dasar dan ketegasan iman. Oleh karena itu, sampai saat ini Gereja tidak pernah mengubah posisi dan keyakinanya bahwa Kristus sendirilah yang yang menyatukan setiap perkawinan sehingga tak terceraikan. Berkaitan dengan hal ini, Paus Yohanes Paulus II dalam Surat Apostoliknya Familiaris Consortio menegaskan bahwa berdasarkan sifat sakramental pernikahan tersebut suami-istri saling terikat yang memungkinkan mereka sama sekali tak terpisahkan. ${ }^{15}$ Atas dasar alasan tersebut Gereja Katolik meyakini bahwa perpisahan terjadi apabila maut memisahkan mereka. Dengan kata lain, kematian yang merupakan campur tangan Allah yang membuat perkawinan itu terputus.

Hal lain yang menarik dari sifat indissolubility atau tak-terceraikannya perkawinan adalah kontra perceraian. Artinya bahwa sifat ini merupakan sebuah nilai fundamental yang harus dibela, terutama saat perceraian membawa dampak negatif yang tak-tersembuhkan. ${ }^{16}$ Perlu ditekankan bahwa pasangan yang bercerai sering kali sangat egoistis dengan memikirkan diri mereka sendiri. Keputusan bercerai dari kedua belah pihak dinilai dapat memecahkan persoalan, nyatanya tidaklah demikian. Perceraian bisa saja membawa dampak yang buruk bagi kesejahteraan keluarga, terutama anak-anak.

${ }^{12}$ Rubiyatmoko, Perkawinan Katolik Menurut Kitab Hukum Kanonik.

13 Yohanes S Lon, "Program KPPK: Upaya Meningkatkan Kesadaran Pasutri Mengenai Hakikat Perkawinan Katolik Di Keuskupan Ruteng,” Randang Tana: Jurnal Pengabdian Masyarakat 3, no. 1 (2020): 1-13.

${ }^{14}$ A. Tjatur Raharso, Paham Perkawinan Gereja Katolik,106.

15 Yohanes Paulus II, Familiaris Consortio (Keluarga), Terjemahan. R. Hardawiryana, Anjuran Apostolik (Jakarta: Dokumentasi dan Penerangan KWI, 2011): 25.

${ }^{16}$ A. Tjatur Raharso, Paham Perkawinan Gereja Katolik. 
Untuk itu, Gereja Katolik selalu berusaha mengedepankan sifat perkawinan ini agar masa depan keluarga tetap utuh dan sejahtera. Mengapa hal ini dipertahankan tentu saja karena Gereja Katolik mengimani bahwa sebagai sebuah sakramen, perkawinan menjadi sebuah jalan yang menyalurkan sekaligus mengaktualisasikan rahmat dan kasih Allah dalam kehidupan. ${ }^{17}$ Memang harus diakui bahwa dalam tataran hidup bersama, konflik dan aneka macam alasan lain yang terkadang berat bisa saja meruntuhkan ikatan suci perkawinan ini. Gereja Katolik tentu saja tidak tinggal diam dan tetap memberikan sarana bantuan untuk mengakomodinir persoalan perkawinan tersebut. Namun, misi Gereja Katolik tetaplah satu dan sama untuk senantiasa menghantar kedua mempelai bersatu kembali. Mengatasi hal tersebut maka sejak awal perkawinan diingatkan bahwa setiap pasangan Katolik yang telah memilih panggilan hidup berkeluarga sangat diharapkan untuk selalu menyadari dan memahami konsekuensi dari pilihan tersebut. Hal yang perlu dilakukan adalah membangun sikap rela berkorban bagi pasangannya dan siap menghayati sakramen perkawinan sesuai dengan ajaran iman Katolik. ${ }^{18}$

\section{Memahami Konteks Pisah Ranjang dalam Kan.1151-1155}

Setelah mengulas secara singkat sifat Perkawinan Katolik, dalam poin ini penulis akan menguraikan konteks "pisah ranjang” dalam Kan. 1151-1155. Uraian ini sangatlah penting untuk membedakannya dengan perpisahan secara sempurna (divirtio). Kan. 1151-1155 merupakan bagian dari artikel 2 Bab XI. Di sini Gereja Katolik memberikan gambaran bagaimana memahami perkara perkawinan yang "sedang" terancam gagal. Tentu saja Gereja Katolik tidak bermaksud memberikan pilihan perceraian sebagai jalan akhir.

Kanon-kanon ini menempatkan posisi Gereja Katolik yang sangat tegas dan dengan hatihati mengurus perkara perpisahan perkawinan. Hal yang ditekankan di sini ialah perpisahan bisa berupa de iure separation, yakni pemutusan hidup bersama secara pemanen atau sementara yang disetujui otoritas publik yang berwenang. Keputusan tersebut diambil setelah melakukan verifikasi oleh otoritas tersebut mengenai adanya alasan yang halal bagi perpisahan itu. ${ }^{19}$ Asumsi ini mempertegas betapa Gereja Katolik berusaha memberikan jalan keluar bagi pasangan agar kemudian diajak untuk bersatu kembali. Pada dasarnya, Gereja Katolik akan selalu mengajak pasangan tersebut untuk kembali bersatu. Hal ini ditegaskan dalam kanon 1151 yang menyatakan, suami-istri mempunyai kewajiban dan hak untuk memelihara hidup bersama perkawinan, kecuali ada alasan legitim yang membebaskan mereka.

Pernyataan dalam kan.1151 ini memperlihatkan komitmen Gereja Katolik dalam mengedepakan hidup bersama sebagai unsur fundamental dalam mencapai tujuan perkawinan. Yang ditampakkan dalam kebersamaan ini adalah ketergantungan satu sama lain dengan menyerahkan diri demi kesejehateraan pasangannya dan juga anak-anak yang lahir dari hasil

17 Theo Uheng Koban Uer, "Perkawinan Katolik Sebagai Jalan Menuju Kesucian,” Atma Reksa: Jurnal Pastoral dan Kateketik 4, no. 1 (2019): 1-13.

18 Theresia Vita Prodeita, "Penghayatan Sakramen Perkawinan Pasangan Suami-Istri Katolik Membuahkan Keselamatan,” Jurnal Teologi 8, no. 1 (2019): 85-106.

${ }^{19}$ A. Tjatur Raharso, Paham Perkawinan Gereja Katolik.,134. 
perkawinan tersebut. ${ }^{20}$ Di sisi lain, fakta menunjukkan bahwa untuk mempertahankan hidup bersama ini bukanlah perkara mudah. Tetapi sejak awal telah ditekankan bahwa tidak dapat disangkal bahwa setiap perkawinan dikemudian hari (setelah menikah) tentu timbul percekcokan dan konflik dengan berbagai macam alasan. Jika persolan itu tidak dapat diselesaikan maka keputusan untuk bersama menjadi alasan bisa dipertahankan lagi.

Berkaitan dengan hal ini, dapat terjadi adanya alasan-alasan yang memungkinkan dibenarkannya perpisahan tidak sempurna. Perpisahan ini tentu saja tetap mempertahankan ikatan perkawinan. Rubiyatmoko menekankan bahwa perpisahan tersebut tidaklah sempurna dan dapat bersifat: pertama, total (berkaitan keseluruhan hidup perkawinan) atau parsial (hanya pisah ranjang, atau pisah meja makan, atau pisah kediaman atau mencakup ketiganya). Kedua, tetap (berkaitan dengan waktu yang tidak ditentukan atau selamanya) atau sementara waktu (hanya untuk kurun waktu tertentu, misalnya satu tahun).

Ketiga, atas inisiatif kedua belah pihak atau atas inisiatif sala satu pihak saja. Keempat, atas prakarsa sendiri atau atas izin kuasa gerejawi yang berwenang (misalnya, oleh Ordinaris wilayah atau tribunal diosesan). Keempat, dapat disebabkan oleh perbuatan zina oleh salah satu pasangan atau karena alasan-alasan yang lain. Berkaitan dengan hal tersebut kanon 1152 menyatakan demikian,

1. Sangat dianjurkan agar pasangan, tergerak oleh cinta kasih kristiani dan prihatin akan kesejahteraan keluarga, tidak menolak mengampuni pihak yang berzinah dan tidak memutus kehidupan perkawinan. Namun jika ia tidak mengampuni kesalahannya secara jelas atau diam-diam, ia berhak untuk memutus hidup bersama perkawinan, kecuali ia menyetujui perzinahan itu atau menyebab- kannya atau ia sendiri juga berzinah.

2. Dianggap sebagai pengampunan diam-diam jika pasangan yang tak bersalah, setelah mengetahui perzinahan itu, tetap hidup bersama secara bebas dengan sikap sebagai seorang pasangan; hal itu diandaikan jika ia meneruskan hidup bersama sebagai suamiistri selama enam bulan, tanpa membuat rekursus pada otoritas gerejawi atau sipil.

3. Jika pasangan yang tak bersalah dari kemauannya sendiri memutus kehidupan bersama perkawinan, hendaknya ia dalam waktu enam bulan mengajukan alasan perpisahan itu kepada otoritas gerejawi yang berwenang; otoritas gerejawi itu hendaknya menyelidiki segala sesuatunya dan mempertimbangkan apakah pasangan yang tak bersalah itu dapat diajak untuk mengampuni kesalahan serta tidak memperpanjang perpisahan untuk seterusnya.

Kanon 1152 ini menerangkan jalan keluar bagi pasangan yang ingin berpisah karena alasan perbuatan zina. Fenomena merebaknya perzinahan dalam kehidupan masyarakat dewasa ini memang telah mengaburkan kesucian ikatan perkawinan. ${ }^{21}$ Dengan kata lain perzinahan itu tentu saja dilihat sebagai perbuatan "yang melukai" sakralitas perkawinan itu sendiri. Mengingat

\footnotetext{
${ }^{20}$ Rubiyatmoko, Perkawinan Katolik Menurut Kitab Hukum Kanonik.,177.

${ }^{21}$ Kartono, "Penerapan Sanksi Pidana Terhadap Pelaku Tindak Pidana Perzinahan," Surya Kencana Satu 09, no. 01 (2018): 19-36.
} 
Gereja Katolik sangat menekankan sifat perkawinan yang satu dan tak-terceraikan, maka dengan sendirinya perbuat zinah sebagai pemicu yang menghancurkan makna kedua sifat tersebut. Gereja menyadari bahwa ketika perpisahan dijadikan sebagai pilihan terakhir maka dampak yang akan diterima selanjutnya akan sanga besar. Memang, di satu sisi juga "pisah ranjang" haruslah merupakan alternatif terakhir yang dapat diambil "dalam keadaan terpaksa" meskipun pihak yang tak bersalah tetap berhak untuk memisahkan diri. ${ }^{22}$

Kanon 1152 ini juga memberikan gambaran yang sangat jelas berkaitan dengan aspek pengampunan dan belas kasih. Gereja tidak langsung memutuskan perpisahan atau atau pemutusan ikatan perkawinan tersebut, tetapi terlebih dahulu mengajak kedua pasangan atau yang melakukan perbuatan zina untuk salinga mengampuni. Artinya bahwa Gereja Katolik sangat mengedepankan cinta kasih sebagai jalan untuk menyatukan kembali pasangan yang ingin berpisah tersebut. Berkaitan dengan hal itu, sangatlah dianjurkan bagi pasangan yang tidak bersalah untuk mengampuni pasangannya. Sebaliknya pula, pihak yang bersalah terikat kewajiban untuk melakukan introspeksi diri, tidak melakukan hal-hal yang semakin menjauhkan dirinya dari pasangannya yang sah, dan selanjutnya melakukan rekonsiliasi dengan pasangannya tersebut. $^{23}$

Harus diakui pula sebagaimana yang ditegaskan dalam Kanon $1153 \S 3$ bahwa perzinahan dari salah satu pasangan, memberikan hak kepada pasangan yang tak bersalah untuk mengadakan perpisahan meja makan, ranjang dan tempat tinggal. Rubiyatmoko menguraikan syarat-syarat perpisahan tersebut. ${ }^{24}$ Pertama, perzinahan sungguh dengan melakukan hubungan seksual dengan lawan jenis. Kedua, perzinahan itu dengan sengaja, tahu dan dengan kemauan. Ketiga, perzinahan tersebut consummatum yakni melakukan hubungan seksual "penuh". Kelima, secara moral pasti (keraguan fakta tidak menghilangkan hak untuk menuntut perpisahan. Kanon 1153 menjelaskan hal tersebut demikian,

1. Jika salah satu pasangan menyebabkan bahaya besar bagi jiwa atau badan pihak lain atau anaknya, atau membuat hidup bersama terlalu berat, maka ia memberi alasan legitim kepada pihak lain untuk berpisah dengan keputusan Ordinaris wilayah, dan juga atas kewenangannya sendiri, bila penundaan membahayakan.

2. Dalam semua kasus itu, bila alasan berpisah sudah berhenti, hidup bersama harus dipulihkan, kecuali ditentukan lain oleh otoritas gerejawi.

Selain alasan perzinahan, Gereja Katolik juga memberikan alasan lain terkait adanya perpisahan pasangan. Satu dari alasan lain tersebut diuraikan dalam Kanon 1153 tersebut. Beberapa alasan tersebut dapat menyangkut bahaya iman seperti bidaah dan kemurtadan, bahaya untuk jiwa, misalnya ditarik ke dalam dosa, penyiksaan fisik dan penyakit menular, persoalan hidup bersama yang sulit dan bisa juga menyangkut bahaya bagi pendidikan anakanak. Pada poin ini, Gereja memberikan pengecualian jika memang kehidupan bersama

\footnotetext{
22 Rubiyatmoko, Perkawinan Katolik Menurut Kitab Hukum Kanonik., 179.

${ }^{23}$ A. Tjatur Raharso, Paham Perkawinan Gereja Katolik.,136.

${ }^{24}$ Rubiyatmoko, Perkawinan Katolik Menurut Kitab Hukum Kanonik., 180.
} 
terancam bahaya. Namun perlu ditegaskan di sini bahwa keputusan "pisah" diambil setelah diputuskan oleh Ordinaris Wilayah (Uskup diosesan atau Vikaris Yudisial) yang tentu saja terlebih dahulu diperiksa dengan teliti dan seksama. Pertimbangannya jelas supaya menghindar jangan sampai setiap orang menentukan sendiri dengan dalil alasannya cukup berat.

Lebih lanjut kanon $1153 \S 2$ menguraikan bahwa perpisahan ini bersifat sementara yakni selama alasan itu masih berlangsung. Hal ini mengandaikan perpisahan tersebut lahir dari keputusan pribadi pasangan. Tetapi lain halnya jika keputusan perpisahan tersebut diberikan oleh pihak Pengadilan Gerejawi, tentu saja harus diperhatikan isi keputusan tersebut. Jadi jelas, Gereja pun tidak pernah mengarahkan perpisahan tersebut pada perceraian. Kanon 1154 mnegtur hal ini dengan mengatakan,Bila terjadi perpisahan suami-istri, haruslah selalu diperhatikan dengan baik sustentasi dan pendidikan yang semestinya bagi anak-anak.

Pada kanon ini Gereja Katalik mempertegas kembali komitmennya tentang tujuan perkawinan itu sendiri. Satu diantaranya adalah memperhatikan kesejahteraan anak-anak. Mengingat "pisah ranjang" dalam hal ini tidak memutuskan ikatan perkawinan, maka sepantasnya pasangan yang berpisah tersebut tetap memperhatikan masa depan anak-anak. Di sini sangat jelas bahwa Gereja Katolik tidak akan "diam diri” menyikapi persoalan perpisahan tersebut, apalagi menyangkut masa depan anak-anak. Terkait hal ini, Paus Yohanes Paulus II menegaskan betapa pentingnya perhatian terhadap hak-hak anak-anak dalam keluarga dengan menumbuhkan sikap menerima, cinta kasih, penghargaan, kepedulian, perhatian dalam semua bidang seperti misalnya di bidang jasmani, emosional, pendidikan dan rohani. ${ }^{25}$ Hal tersebut ditekankan dalam kanon 1155 yang mengatakan bahwa, terpujilah bila pasangan yang tak bersalah dapat menerima kembali pihak yang lain untuk hidup bersama lagi; dalam hal demikian ia melepaskan haknya untuk berpisah. Perpisahan pada dasarnya merupakan sebuah peristiwa yang tidak dikehendaki oleh mereka yang merindukan kebahagiaan di dalam kehidupan mereka.

Pada akhirnya, Gereja Katolik selalu mengajak suami dan isteri yang mau "berpisah" untuk kembali. Sekali lagi aspek pengampunan atau belas kasih menjadi kata kunci agar kehidupan rumah tangga dapat dihidupi kembali. ${ }^{26}$ Keutuhan keluargalah yang harus dikejar dan dipertahankan sekalipun tantangan terus datang. Cinta adalah fondasi dasar untuk membangun dan menghidupkan rumah tangga. Untuk itu pasangan yang mau berpisah, diajak kembali bersatu dalam cinta yang mendasari perkawinan mereka. ${ }^{27}$ Sebab pengalaman cinta dalam keluarga-keluarga adalah sumber kekuatan abadi bagi kehidupan Gereja.

${ }^{25}$ Yohanes Paulus II, Familiaris Consortio (Keluarga).,45.

${ }^{26}$ Rubiyatmoko, Perkawinan Katolik Menurut Kitab Hukum Kanonik.

${ }^{27}$ Paus Fransiskus, Amoris Laetitia (Sukacita Kasih), Terjemahan.Komisi Keluarga KWI dan Couple for Christ Indonesia, Seruan Apostolik Pascasinode (Jakarta: Dokumentasi dan Penerangan KWI, 2018).52. 


\section{“Pisah Ranjang” dalam Konsep Sifat tak-terputuskannya Perkawinan Katolik Menurut Kanon 1151-1155}

Setelah meguraikan sifat Perkawinan Katolik dan Kanon 1151-1151, pada poin ini penulis akan memaparkan keterkaitannya satu sama lain. Sekali lagi ditegaskan bahwa Gereja Katolik tidak pernah menginginkan dan membenarkan adanya perceraian. Memang sebagaimana yang dikatakan sebelumnya bahwa Gereja Katolik juga mengurus perkara persoalan perkawinan yang dalam keadaan tertentu diputuskan atau dibatalkan. Gereja menyebutnya anulasi. Berkaitan dengan itu Kitab Hukum Kanonik mengakomodir hukum atau aturan terkait anulasi tersebut. Penulis tentu saja tidak menguraikan poin tersebut. Fokus tulisan ini lebih kepada perpisahan sementara yang dalam arti tertentu banyak dialami oleh keluarga-keluarga katolik. Kanon 11511155 secara terperinci mengulas tentang perpisahan sementera tersebut yang sudah penulis uraikan.

Dari penjelasan di atas dapat dipahami bahwa "pisah ranjang" in se tidak memutuskan ikatan perkawinan. ${ }^{28}$ Gereja Katolik dalam hal ini tetap pada komitmennya bahwa mereka tetaplah suami dan isteri yang sah. Dengan demikian sekalipun mereka memilih untuk "berpisah" dengan berbagai alasan, sifat indissolubilitas (tak-terceraikan) perkawinan tetap melekat. Asumsi dasar ini mempertegas kembali pendirian Gereja Katolik akan martabat dan keluhuran perkawinan suci. Mengapa Gereja Katolik sangat menentang perceraian?

Komitmen Gereja Katolik untuk mempertahankan ikatan perkawinan yang takterceraikan tidak pernah pudar. Selain didasari keyakinan akan relasi kasih antara Allah dan umat-Nya, Kristus dan Gereja, ditambah pula berbagai pernyataan dalam Kitab Suci. Pernyataan Yesus dalam Perjanjian Baru mempertegas lagi komitmen Gereja Katolik. Yesus menegaskan bahwa "Demikianlah mereka bukan lagi dua, melainkan satu. Karena itu, apa yang telah dipersatukan Allah, tidak boleh diceraikan manusia." Campur tangan Allah sangat nampak dalam konteks perkawinan Katolik dan dengan demikian perceraian itu tidak sesuai dengan kehendak Tuhan (Mat. 19:8). ${ }^{29}$ Pemisahan pasangan hanya mungkin terjadi jika salah satu pasangan meninggal. Dengan demikian dapat dikatakan bahwa perkawinan tak terceraikan mempertegas bahwa konflik rumah tangga seberat apa pun yang dialami oleh pasangan menikah tidak bisa membuat perkawinan dibubarkan atau diceraikan. ${ }^{30}$

Adanya perpisahan yang terjadi dalam perjalanan waktu tentu saja tidak membatalkan ikatan perkawinan. Kanon 1151-1155 memang memberikan arahan atau rambu untuk mengakomodinir persoalan pasangan yang ingin pisah, namun bukan dalam konteks perceraian. Jadi jelas di sini Gereja Katolik tetap "melawan" perceraian. Terkait hal ini penulis mengafirmasi bahwa dalam legislasi kanonik, perpisahan bukanlah langkah awal menuju perceraian, sekalipun perceraian sering kali didahului dengan perpisahan unilateral atau berdasarkan kesepakatan kedua pihak. Adanya perpisahan yang diatur dalam Kanon 1151-1555

\footnotetext{
${ }^{28}$ Rubiyatmoko, Perkawinan Katolik Menurut Kitab Hukum Kanonik.

${ }^{29}$ Yohanes Servatius Lon, Hukum Perkawinan Sakramental Dalam Gereja Katolik: 45.

${ }^{30}$ Ibid.,41.
} 
memiliki tujuan yang fundamental dalam rangka menjunjung tinggi harkat dan martabat perkawinan, serta untuk memulihkan kehidupan perkawinan tersebut. Dengan demikian dapat dikatakan secara tegas bahwa perpisahan memiliki dimensi yang lebih positif daripada perceraian. Secara positif memaksudkan perpisahan yang mengandung unsur pedagogis bagi pasangan suami-isteri itu, dan tidak bertentangan dengan dinamika orang beriman untuk selalu bertumbuh-kembang untuk mencapai kesempurnaan cinta-kasih kristiani.

Lebih lanjut perlu ditekankan di sini bahwa pisah-ranjang sebenarnya menjadi sarana untuk berfleksi dan menginstropeksi diri. Berkaitan dengan hal ini Tjatur Raharso menerangkan bahwa pisah ranjang yang disertai dengan refleksi dan instrospeksi diri kedua pasangan, yang kemudian dilanjutkan dengan pertobatan oleh pasangan yang bersalah dan pengampunan oleh pasangan yang tidak bersalah, dan diakhiri dengan pulihnya hidup perkawinan, semuanya itu akan mengantar pasangan itu masuk ke dalam babak baru relasi kasih yang lebih dewasa dan matang, serta kepada kesabaran, kerendahan hati, dan saling pengertian yang lebih besar. Meskipun halnya sangat sulit dan berat, namun itulah kekhasan dan kekuatan cinta-kasih kristiani. $^{31}$

Kanon 1151-1155 sudah sangat jelas menghantar kedua pasangan untuk tidak memilih berpisah selamanya tetapi diselesaikan secara damai dalam belas kasih dan pengampunan. Aspek ini sangat penting untuk memperkuat keutuhan rumah tangga dan kesejahteraan anakanak. Proses rekonsiliasi dan pemberian diri ini menjadi kunci dalam membangun kebersamaan dan ketergantungan satu sama lain relasi suami-isteri ${ }^{32}$. Kekuatan rekonsiliasi sangat ampuh dalam mengatasi keinginan berpisah ini walaupun harus diakui tidaklah mudah. Namun justru di sinilah hidup rumah tangga diuji kesetiaannya. Untuk itu dalam hal ini suami-isteri sejatinya harus selalu menyadari bahwa masing-masing diciptakan menjadi anugerah dan penolong yang membuat pasangannya mencapai kebahagiaan yang sempurna.

\section{Kesimpulan}

Perkawinan Katolik pada intinya sangat menjunjung tinggi sifatnya yang monogami dan tak-terceraikan. Gereja Katolik mengimani perkawinan sebagai gambaran persatuan Allah dan Umat-Nya Israel, antara Kristus dan Gereja-Nya sebagai mempelai. Allah sendirilah yang mempersatukan pria dan wanita dalam ikatan suci perkawinan tersebut. Untuk itu, tidak sedikitpun dari pihak Gereja memiliki hak menceraikan apa yang telah dipersatukan Allah, kecuali maut. Menghayati hidup dalam ikatan perkawinan suci memang tidak mudah. Bukan hal baru bahwa banyak ditemukan adanya pasangan yang memilih untuk berpisah dengan berbagai macam alasan. Tak terkecuali hal ini juga menyeret kehidupan rumah tangga umat Katolik. Ada yang sudah berpisah tanpa sepengetahuan Gereja dan ada juga yang memilih untuk hidup dengan pasangan lain.

${ }^{31}$ A. Tjatur Raharso, Paham Perkawinan Gereja Katolik.

${ }^{32}$ Agung Prihartana, Menjadi Anugerah Bagi Pasangan (Yogyakarta: Pusat Pendampingan Keluarga (PPK) MSF, 2012): 84. 
Menyikapi hal ini, dengan tetap memperhatikan komitmennya untuk mempertahankan perkawinan suci, Gereja dalam hal para Petugas Pastoral berusaha secara hati-hati dan teliti dalam mengurus perkara perpisahan tersebut. Gereja Katolik dalam hal ini menyedikan sarana bantuan untuk mengurus perkara perkawinan tersebut yang disebut Vikaris Yudensial (Pengadilan Gerejawi). Biasanya keputusan akhir dari perkara ini jika memang disetujui adalah pembatalan atau pemutusan ikatan perkawinan (anulasi) bukan perceraian versi katolik.

Gereja Katolik dalam Kitab Hukum Kanonik memberikan penekankan pada persoalan perpisahan tersebut, ada yang bersifat sempurna dan ada yang sementara. Kanon 1151-1155 mengulas perkara perpisahan sementara dengan tetap memiliki ikatan perkawinan. Kanon ini kerap menyinggung soal "pisah ranjang". Uraian-uraian di atas telah membahas konsep "pisah ranjang tersebut dalam keterkaitannya dengan sifat perkawinan yang tak-terceraikan. Pilihan "pisah ranjang" sejatinya merupakan alternatif terakhir Gereja Katolik jika belum menemukan titik terang. Untuk itu apa yang ditegaskan dalam kanon-kanon tersebut bukan terarah pada perceraian, tetapi sebaliknya mengajak kedua pasangan untuk kembali bersatu jika memang telah terjadi persoalan. Jika memang berpisah pun tidak akan pernah mematahkan persatuan ikatan perkawinan tersebut.

Di sisi lain, penulis mengamini bahwa tidak semua umat Katolik yang memahami konteks "pisah ranjang" ini. Tidak jarang ada yang memilih berpisah tetapi kemudian menjadikan kesempatan tersebut untuk memilih pasangan lain. Padahal pilihan "pisah ranjang" sejatinya adalah saat untuk menginstropeksi diri (refleksi) dan memutuskan yang terbaik bagi masa depan keluarga. Untuk itu penulis memberikan rekomendasi terutama dengan meningkatkan kembali katekese paham perkawinan supaya umat tidak salah paham berkaitan dengan "pisah ranjang" ini. Selain itu, dengan penelitian ini memaksudkan juga bagi para pasangan yang mengalami persoalan untuk terbuka kepada Pastor Paroki sebagai wakil uskup.

\section{Referensi}

A. Tjatur Raharso. Paham Perkawinan Gereja Katolik. Malang: Dioma, 2014.

Agung Prihartana. Menjadi Anugerah Bagi Pasangan. Yogyakarta: Pusat Pendampingan Keluarga (PPK) MSF, 2012.

Alfian Hadyanto Purnadi. "Perpisahan Hidup Perkawinan Menurut Kitab Hukum Kanonik (KHK) Kanon 1151-1155 Dalam Hubungannya Dengan Sistem Perundangan Indonesia.” Lex et Societatis II, no. 3 (2014).

Badan Pusat Statistik. "Jumlah Nikah, Talak Dan Cerai, Serta Rujuk (Pasangan Nikah), 20142016."

Galed, Daniel Ortega, and Latar Belakang. "Perkawinan In Fieri Dan Perkawinan In Facto Esse Dalam Pemahaman Yuridis Gereja Katolik.” Hukum Magnus Opus 3, no. 1 (2020): 5768.

II, Yohanes Paulus. Kitab Hukum Kanonik (Codex Iuris Canonici). Jakarta: Konferensi Wali Gereja Indonesia, 1983. 
Jefrie Walean: Polemik Memakan Darah: Studi Kasus dalam Sidang di Yerusalem

Kartono. "Penerapan Sanksi Pidana Terhadap Pelaku Tindak Pidana Perzinahan." Surya Kencana Satu 09, no. 01 (2018): 19-36.

Konsili Vatikan II. Lumen Gentium (Terang Bangsa-Bangsa). Jakarta: Dokumentasi dan Penerangan KWI, 1990.

Lon, Yohanes S. "Program KPPK : Upaya Meningkatkan Kesadaran Pasutri Mengenai Hakikat Perkawinan Katolik Di Keuskupan Ruteng." Randang Tana: Jurnal Pengabdian Masyarakat 3, no. 1 (2020): 1-13.

Paus Fransiskus. Amoris Laetitia (Sukacita Kasih). Edited by Terjemahan.Komisi Keluarga KWI dan Couple for Christ Indonesia. Seruan Apostolik Pascasinode. Jakarta: Dokumentasi dan Penerangan KWI, 2018.

Prodeita, Theresia Vita. "Penghayatan Sakramen Perkawinan Pasangan Suami-Istri Katolik Membuahkan Keselamatan.” Jurnal Teologi 8, no. 1 (2019): 85-106.

Rubiyatmoko, Robertus. Perkawinan Katolik Menurut Kitab Hukum Kanonik. Yogyakarta: Kanisius, 2011.

Sujarwa. Ilmu Sosial Dan Budaya Dasar, Manusia Dan Fenomena Sosial Budaya. Yogyakarta: Pustaka Pelajar, 2010.

Theo Uheng Koban Uer. "Perkawinan Katolik Sebagai Jalan Menuju Kesucian." Atma Reksa: Jurnal Pastoral dan Kateketik 4, no. 1 (2019): 1-13.

Tim, CNN Indonesia. "Catatan Kemenag: Rata-Rata 300 Ribu Perceraian Tiap Tahun."

Yohanes Paulus II. Familiaris Consortio (Keluarga). Edited by Terjemahan. R. Hardawiryana. Anjuran Apostolik. Jakarta: Dokumentasi dan Penerangan KWI, 2011.

Yohanes Servatius Lon. Hukum Perkawinan Sakramental Dalam Gereja Katolik. Yogyakarta: Kanisius, 2019. 